\title{
Geotechnical Characterization and Suitability of Dredged Material from Jhelum Flood spill channel for its potential use as Construction Material.
}

\author{
Zaid Yaqoob Mir Rangrez ${ }^{1 * *}$, Zohaib Ahmad Khan ${ }^{1}$, Ghazi Mohd. Mustaqeem", \\ Barkat Hussain Khan ${ }^{2}$, Ajaz Masood Bhat ${ }^{3}$. \\ ${ }^{l}$ B.E, Department of Civil Engineering, SSMCOET, University Of Kashmir, Srinagar, Jammu \& Kashmir. \\ ${ }^{2}$ Visiting Professor, Department of Civil Engineering, SSMCOET, University Of Kashmir, J\&K. \\ ${ }^{3}$ Research Officer, Road Research And Material Testing Laboratory, Srinagar, Jammu \& Kashmir.
}

\section{ABSTRACT}

Occurrence of floods in the Kashmir valley in September 2014 compelled the Govt. of Jammu and Kashmir to take the necessary steps in order to avoid the similar situation in near future. Eventually the Govt. decided to start dredging of Jhelum and its spill channel, in order to increase their capacity. As a result, a large quantity of dredged material will be obtained and there should be a proper plan in advance for the utilization of such a large quantity of dredged material. Dredged material can no longer be thrown away as a waste material. The use of dredged material can be made in the development of numerous development projects which can reduce the exploitation of primary resources needed for construction activities. But before putting the dredged material to some constructional use, it is essential to carry out investigation for its characterization and only then it can be utilized judiciously, depending on its geotechnical merit. In the present study, samples were retrieved from four locations of the Jhelum flood spill channel bed. Experimental investigations were carried out to determine the various geotechnical parameters related to the physical and engineering properties of the material. The material was classified using Indian Standard Classification System. It had been observed that the material available at these locations was predominantly fine grained inorganic silt, clayey silt with little amount of fine sand and some traces of organic matter. Based on the geotechnical characterization, the material had been critically found suitable for its potential use in embankment cores, canal linings, clay liners, landfill for low lying areas and also as compacted foundation/subgrade material.

Keywords: Dredged material, Geotechnical parameters, Geotechnical characterization, Impervious cores, Clay liners, Subgrade, Landfills, Canal lining.

\section{INTRODUCTION}

In September 2014, water level in the Jhelum river reached to such an excessive height that the water overflowed its banks and inundated almost all of Kashmir valley. It caused intensive damage in terms of loss of life, property and disruption of economic activities. According to Irrigation and Flood control department of Jammu and Kashmir, the state's river and flood channels could carry around 65,000 cusecs of water, while in September 2014 the discharge was over 100,000 cusecs. Moreover, the drainage channels of the region have been blocked and the links between the lakes have been cut off due to unplanned urbanization and encroachment and as a consequence, the lakes have lost their power to absorb water the way they used to, a century ago, and save the region from floods[1]. Moreover, the encroachment of river banks along the Jhelum and its tributaries had been a bane for Kashmir for several years. A large number of illegal structures had mushroomed along the banks of the Jhelum in North and South Kashmir in Anantnag, Srinagar, Bandipora, and Baramulla districts, thus reducing the carrying capacity of the system. Illegal construction was rampant at Khanbal, Bijbehara, Sangam, Halmula, Kakpora, Samboora, Guru and Padhgampura. It was also revealed that deforestation in the Jhelum basin led to excessive siltation in Jhelum and its water courses. Due to this the capacity of Jhelum has been effected. Continuous rains for two to three days in Kashmir valley raises flood threat in the Jhelum river. No such risk arose with this much of precipitation two to three decades back. Therefore, there was a rising need for the Govt. of Jammu and Kashmir to take necessary steps so that the rising threat of floods that is looming large over the Kashmir valley is avoided. Fortunately, the government eventually has announced its step to undertake the dredging of river Jhelum and its spill channel. Now one of the consequences will be that a 
large quantity of dredged material will be obtained from the beds of river Jhelum and its spill channel. For this, there should be a proper plan in advance to deal with this large quantity of dredged material. Dredged material is no longer something we simply throw away. At a time when communities are looking for innovative ways to recycle and maintain or improve the current environmental condition, we must look for ways to beneficially reuse the dredged material. The use of dredged material has a major contribution to make to sustainable development and can reduce the quantities of primary resources needed for activities such as construction and habitat creation. But, before taking any decision regarding the beneficial use of the dredged material we first need to carry out investigation for its characterization in order to check its suitability for various uses and only after that a rational decision can be made regarding its use. In recent times, various studies exploring the potential of dredged material for use as a material for construction purpose have been conducted in different parts of the world. Evangelin Ramani Sujatha et al., (2013), [2], evaluated the geotechnical parameters of material obtained from Kollidam river bed in Tamil Nadu. In this study, attempts had been made to characterize the soil and supplement its geotechnical properties with its mineralogical composition. Hua Yu and William J. Likos, (2014), [3], conducted the investigation on dredged material obtained from various harbours and confined disposal facilities in Great Lakes region in US. The study has been confined to identification of suitability of dredged materials in transportation construction as pavement sub-base, pavement base course aggregate, construction fill. Laboratory tests were conducted to determine the Particle size distribution, Atterberg limits, Compaction characteristics, Resilient modulus, Compressibility characteristics, and Coefficient of permeability of the dredged material. M. R. Das et al., (2014), [4], evaluated the geotechnical parameters of mud obtained from Chilka Lake. The same methodology of laboratory investigation was employed to determine the Void ratio, Porosity, Particle size analysis, Specific gravity, Atterbergs consistency limits, Differential free swell index and Compaction characteristics of the retrieved sample. Walid Maherzi and Farouk Ben Abdelghani, (2014), [5], working under a large Research European Interreg IVA program, SETARMS, conducted the physical and geotechnical characterization of dredged material sampled from different French ports for its suitability as subgrade layer. C. Sheehan et al., (2008), [6], in their investigation for beneficial use of dredged material in Ireland, employed the physical and chemical tests to establish the suitability of dredged material from three ports. In another study, samples of processed Construction \& Demolition waste and dredge material were collected from locations in Cork City and Cork County to characterise the materials. The C\&D samples were obtained from stockpiles at two recycling centres in Cork City and the dredge samples by grab sampling, from the bucket of a dredger or from mudflats at various locations in Ireland. Ten samples of waste materials were tested, $3 \mathrm{C} \& D$ samples and 7 dredge samples. One additional sample of a typical clay which was in use as a landfill liner was also tested for Particle size distribution, Consistency limits, Organic content, Light compaction, Particle density, and Hydraulic conductivity. The analysis of the samples of the C\&D waste and the dredge material indicated that it would be technically feasible to prepare a composite sample from the two materials which would satisfy the requirements of the compacted clay liner. Thus for exploring the engineering applications of dredged material, geotechnical characterization forms an important consideration. Geotechnical characterization includes determination of physical as well as engineering properties of the material. By knowing these properties, one can then allocate the material to some use depending on its geotechnical characteristics.

\section{MATERIALS AND METHODS}

In the present study, disturbed as well as undisturbed samples have been taken from four sites along the bed of Jhelum flood spill channel. Open excavation method has been employed for retrieving samples. One core has been retrieved from each site. The samples have been retrieved from within the depth range of 1 to $1.5 \mathrm{~m}$ below the existing flood spill channel bed level. All the positions have been marked with GPS for future references.

Table 1. GPS Coordinates for various sampled sites

\begin{tabular}{|c|c|c|c|c|}
\hline SAMPLE NO. & 1 & 2 & 3 & 4 \\
\hline GPS & N 34 $03^{\prime} 30.7^{\prime \prime}$ & N 34 $04^{\circ} 15.6^{\prime \prime}$ & N 34 $4^{\circ} 03^{\prime} 31.6^{\prime \prime}$ & N 34 $04^{\circ} 14.7^{\prime}$ \\
\hline COORDINATES & E $74^{\circ} 49^{\prime} 35.6^{\prime \prime}$ & Е $74^{\circ} 48^{\prime} 19.6^{\prime \prime}$ & E $74^{\circ} 49^{\prime} 16^{\prime \prime}$ & E $74^{\circ} 47^{\prime} 53.1^{\prime \prime}$ \\
\hline
\end{tabular}




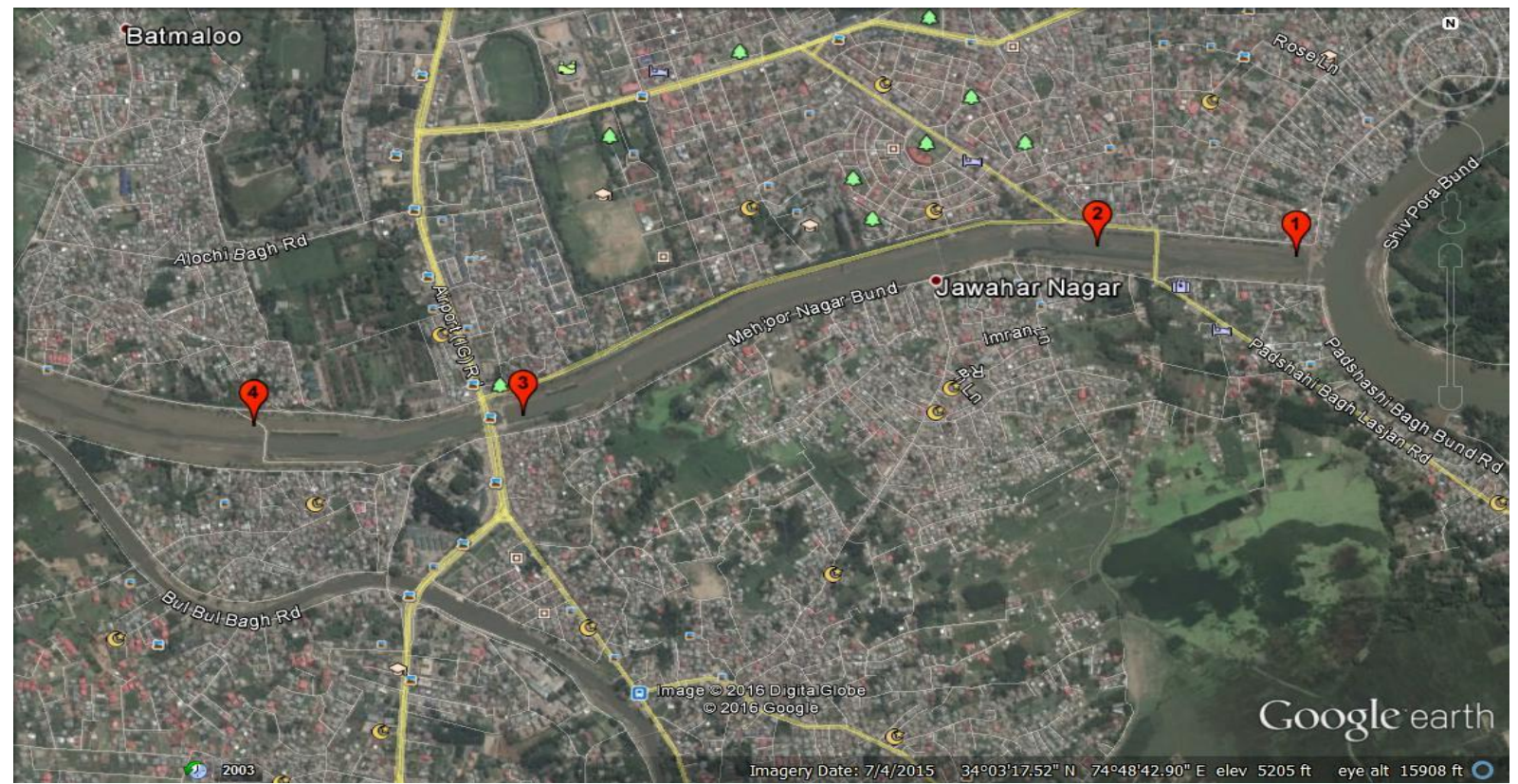

Plate 1. Satellite Map showing the sites (marked with red place marks) from where the samples have been retrieved for Geotechnical characterisation.

All the samples have been tested according to relevant IS codes in the laboratory for determining the geotechnical parameters, as given in Table 2. The specific gravity of various samples have been determined using density bottle method and the liquid limits have been determined using Casagrande's apparatus. Also the various geotechnical parameters have been determined after compacting the samples to max. dry density at optimum moisture content obtained from corresponding Standard proctor compaction test for that sample. The coefficient of permeability has been obtained indirectly from the corresponding consolidation test for the corresponding samples using Taylor's square root of time method.

Table 2. Tests for characterization of dredged material.

\begin{tabular}{|c|c|c|c|}
\hline S.No. & & EST & PROCEDURE AS PER IS CODE NO. \\
\hline 1 & \multicolumn{2}{|c|}{ In-situ density test } & IS $2720-29(1975)$ \\
\hline 2 & \multicolumn{2}{|c|}{ Specific gravity test } & IS 2720-3 (1980) \\
\hline 3 & \multicolumn{2}{|c|}{ Liquid limit test } & IS 2720-5 (1985) \\
\hline 4 & \multicolumn{2}{|c|}{ Plastic limit test } & IS 2720-5 (1985) \\
\hline \multirow[t]{2}{*}{5} & \multirow{2}{*}{$\begin{array}{c}\text { Particle size } \\
\text { distribution }\end{array}$} & Wet sieve analysis & IS 2720-4 (1985) \\
\hline & & Hydrometer analysis & IS2720-4 (1985) \\
\hline 6 & \multicolumn{2}{|c|}{ Standard proctor test } & IS 2720-7 (1980) \\
\hline 7 & \multicolumn{2}{|c|}{ California bearing ratio test } & IS 2720-16 (1987) \\
\hline 8 & \multicolumn{2}{|c|}{ Unconfined compressive strength test } & IS $2720-10(1991)$ \\
\hline 9 & \multicolumn{2}{|c|}{ Direct shear test } & IS 2720-13 (1986) \\
\hline 10 & \multicolumn{2}{|c|}{ Consolidation test } & IS 2720-15 (1965) \\
\hline
\end{tabular}

\section{RESULTS}


Zaid Yaqoob Mir Rangrez.et.al. Int. Journal of Engineering Research and Application www.ijera.com ISSN : 2248-9622, Vol. 7, Issue 1, ( Part -2) January 2017, pp.11-21

The various properties of the samples obtained are given in Table 3 :

Table 3. Dredged Material characteristics

\begin{tabular}{|c|c|c|c|c|c|c|c|c|c|c|c|c|c|}
\hline S.No & Properties & \multicolumn{3}{|c|}{ SAMPLE 1} & \multicolumn{3}{|c|}{ SAMPLE 2} & \multicolumn{3}{|c|}{ SAMPLE 3} & \multicolumn{3}{|c|}{ SAMPLE 4} \\
\hline 1. & In-situ dry density. & \multicolumn{3}{|c|}{$1.256 \mathrm{~g} / \mathrm{cm}^{3}$} & \multicolumn{3}{|c|}{$1.411 \mathrm{~g} / \mathrm{cm}^{3}$} & \multicolumn{3}{|c|}{$1.530 \mathrm{~g} / \mathrm{cm}^{3}$} & \multicolumn{3}{|c|}{$1.538 \mathrm{~g} / \mathrm{cm}^{3}$} \\
\hline 2. & In-situ bulk density. & \multicolumn{3}{|c|}{$1.834 \mathrm{~g} / \mathrm{cm}^{3}$} & \multicolumn{3}{|c|}{$1.839 \mathrm{~g} / \mathrm{cm}^{3}$} & \multicolumn{3}{|c|}{$1.865 \mathrm{~g} / \mathrm{cm}^{3}$} & \multicolumn{3}{|c|}{$1.927 \mathrm{~g} / \mathrm{cm}^{3}$} \\
\hline 3. & $\begin{array}{l}\text { In-situ moisture } \\
\text { content. }\end{array}$ & \multicolumn{3}{|c|}{$46.04 \%$} & \multicolumn{3}{|c|}{$30.31 \%$} & \multicolumn{3}{|c|}{$21.89 \%$} & \multicolumn{3}{|c|}{$25.30 \%$} \\
\hline 4. & Specific gravity & \multicolumn{3}{|c|}{2.61} & \multicolumn{3}{|c|}{2.63} & \multicolumn{3}{|c|}{2.60} & \multicolumn{3}{|c|}{2.61} \\
\hline \multirow[t]{2}{*}{5.} & \multirow[t]{2}{*}{ Gradation. } & ¿্য & $\begin{array}{l}\text { : } \\
\text { ผี }\end{array}$ & $\begin{array}{l}\stackrel{\vec{\Xi}}{U} \\
+ \\
\stackrel{ \pm=}{\bar{n}}\end{array}$ & $\begin{array}{l}\overline{0} \\
\stackrel{\pi}{0}\end{array}$ & चี & $\begin{array}{l}\stackrel{\vec{\Xi}}{0} \\
+ \\
\stackrel{=}{=}\end{array}$ & ¿ & ह్ & $\begin{array}{l}\frac{\vec{\sigma}}{0} \\
+ \\
\stackrel{+}{=}\end{array}$ & $\sum_{i}^{\overline{0}}$ & $\begin{array}{l}\vec{E} \\
\text { जू }\end{array}$ & $\begin{array}{l}\stackrel{\vec{\Xi}}{0} \\
+ \\
\stackrel{ \pm}{=}\end{array}$ \\
\hline & & \&̊ & $\begin{array}{l}\stackrel{0}{0} \\
\infty \\
\\
\end{array}$ & 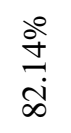 & 80 & 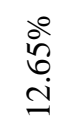 & 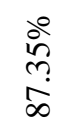 & 80 & $\stackrel{\stackrel{0}{\sim}}{\stackrel{\sim}{\sim}}$ & $\begin{array}{l}\frac{\infty}{\infty} \\
\infty \\
\dot{a} \\
\end{array}$ & 80 & $\begin{array}{l}\stackrel{0}{0} \\
\stackrel{0}{0} \\
0\end{array}$ & 官 \\
\hline 6. & Liquid limit $^{*}$ & \multicolumn{3}{|c|}{$25 \%$} & \multicolumn{3}{|c|}{$36 \%$} & \multicolumn{3}{|c|}{$33 \%$} & \multicolumn{3}{|c|}{$45 \%$} \\
\hline 7. & Plastic limit ${ }^{*}$ & \multicolumn{3}{|c|}{$19 \%$} & \multicolumn{3}{|c|}{$21 \%$} & \multicolumn{3}{|c|}{$19 \%$} & \multicolumn{3}{|c|}{$22 \%$} \\
\hline 8. & Plasticity index ${ }^{*}$ & & $6^{c}$ & & & $15 \%$ & & & $14 \%$ & & & $23 \%$ & \\
\hline 9. & Classification & & CL- & & & $\mathrm{CI}$ & & & $\mathrm{CL}$ & & & $\mathrm{CI}$ & \\
\hline 10. & Flow index $\left(\mathrm{I}_{\mathrm{f}}\right)$ & & 6.6 & & & 4.15 & & & 4.9 & & & 8.64 & \\
\hline 11. & Toughness index $\left(I_{t}\right)$ & & 0.9 & & & 3.66 & & & 2.7 & & & 2.64 & \\
\hline 12. & $\begin{array}{l}\text { Max dry density } \\
\text { (light compaction) }\end{array}$ & & .732 & $/ \mathrm{cm}^{3}$ & & $534 \mathrm{~g}$ & $\mathrm{~cm}^{3}$ & & $.69 \mathrm{~g} /$ & $\mathrm{cm}^{3}$ & & $52 \mathrm{~g} / \mathrm{c}$ & \\
\hline 13. & $\begin{array}{l}\text { OMC (light } \\
\text { compaction) }\end{array}$ & & 18 & & & $25 \%$ & & & $16 \%$ & & & $21 \%$ & \\
\hline 14. & $\begin{array}{l}\text { CBR value (soaked } \\
\& \text { light compaction) }\end{array}$ & & 4.5 & & & 3.45 & & & 0.94 & & & $2.11 \%$ & \\
\hline 15. & $\begin{array}{l}\text { Unconfined } \\
\text { compressive } \\
\text { strength }\left(\mathrm{q}_{\mathrm{u}}\right)\end{array}$ & & $.92 \mathrm{k}$ & $/ \mathrm{cm}^{2}$ & & $65 \mathrm{~kg}$ & $\mathrm{~cm}^{2}$ & & $45 \mathrm{~kg}$ & $\mathrm{~cm}^{2}$ & & $4 \mathrm{~kg} / \mathrm{c}$ & \\
\hline 16. & $\begin{array}{l}\text { Undrained shear } \\
\text { strength }\left(\mathrm{c}_{\mathrm{u}}\right)\end{array}$ & & $.49 \mathrm{k}$ & $/ \mathrm{cm}^{2}$ & & $36 \mathrm{~kg}$ & $\mathrm{~cm}^{2}$ & & $87 \mathrm{~kg}$ & $\mathrm{~cm}^{2}$ & & $9 \mathrm{~kg} / \mathrm{c}$ & \\
\hline 17. & $\begin{array}{l}\text { Angle of shear } \\
\text { resistance }(\varphi)^{*}\end{array}$ & & 18 & & & $23^{\circ}$ & & & $19^{\circ}$ & & & $23^{\circ}$ & \\
\hline 18. & $\begin{array}{l}\text { Cohesion intercept } \\
\text { (c) }\end{array}$ & & $097 \mathrm{k}$ & $/ \mathrm{cm}^{2}$ & & $08 \mathrm{~kg}$ & $\mathrm{~cm}^{2}$ & & $18 \mathrm{~kg}$ & $\mathrm{~cm}^{2}$ & & $2 \mathrm{~kg} / \mathrm{c}$ & \\
\hline 19. & $\begin{array}{l}\text { Coefficient of } \\
\text { compressibility }\left(a_{v}\right)\end{array}$ & & $011 \mathrm{c}$ & $\mathrm{n}^{2} / \mathrm{kg}$ & & $021 \mathrm{cn}$ & ${ }^{2} / \mathrm{kg}$ & & $013 \mathrm{cr}$ & $\mathrm{n}^{2} / \mathrm{kg}$ & 0.0 & $15 \mathrm{~cm}$ & $/ \mathrm{kg}$ \\
\hline 20. & $\begin{array}{l}\text { Coefficient of } \\
\text { consolidation }\left(c_{v}\right)\end{array}$ & & $\begin{array}{r}.61 \times \\
\mathrm{cm}\end{array}$ & $\begin{array}{l}10^{-2} \\
\text { s }\end{array}$ & & $\begin{array}{r}271 \times \\
\mathrm{cm}^{2} /\end{array}$ & $10^{-2}$ & & $\begin{array}{r}194 \times \\
\mathrm{cm}^{2}\end{array}$ & $\begin{array}{l}10^{-2} \\
\mathrm{~s}\end{array}$ & & $\begin{array}{l}07 \times 1 \\
\mathrm{~cm}^{2} / \mathrm{s}\end{array}$ & \\
\hline 21. & $\begin{array}{l}\text { Compressibility } \\
\text { index }\left(\mathrm{C}_{\mathrm{c}}\right)\end{array}$ & & 0.1 & & & 0.16 & & & $0.09^{\prime}$ & & & 0.116 & \\
\hline 22. & Swelling index $\left(\mathrm{C}_{\mathrm{e}}\right)$ & & 0.0 & & & 0.01 & & & 0.02 & & & 0.018 & \\
\hline 23. & $\begin{array}{l}\text { Coefficient of } \\
\text { permeability }(\mathrm{k})\end{array}$ & & $\begin{array}{r}.47 \times \\
\mathrm{m}\end{array}$ & $10^{-9}$ & & $\begin{array}{r}78 \times 1 \\
\mathrm{~m} / \mathrm{s}\end{array}$ & $0^{-9}$ & & $\begin{array}{r}15 \times \\
\mathrm{m} / \mathrm{s}\end{array}$ & $10^{-9}$ & & $\begin{array}{c}0 \times 1 \\
\mathrm{~m} / \mathrm{s}\end{array}$ & \\
\hline
\end{tabular}

approximate values.

IV. DISCUSSION

4.1 Particle size distribution
The particle size distribution of the material reveals it to be predominantly fine grained with small amount 
of sand and major portion of clayey silt/silt. The particle size distribution curves for the four samples are shown in Fig 1.

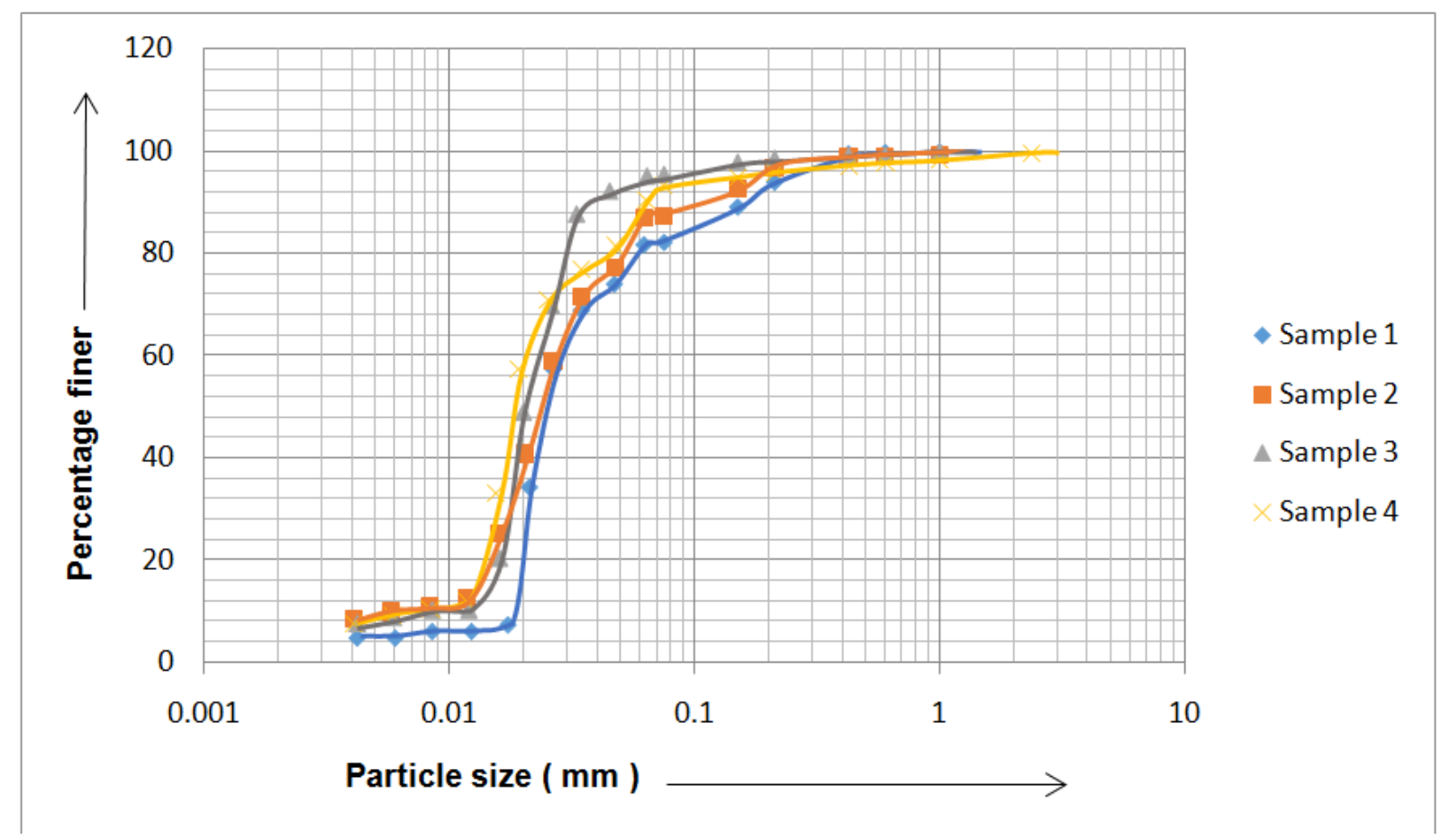

Fig 1 Particle size distribution curves.

\subsection{Specific gravity}

Specific gravity of samples range from 2.60 to 2.63 which is a little low for a fine grained soil. This may be due to the presence of little amount of organic content in the soil.

\subsection{Atterberg limits}

The values of liquid and plastic limits for the tested samples are given in Table 3 . It has been observed that the flow indices of sample 4 and sample 1 are high depicting their higher rate of decrease in shear strength with increase in water content. The flow indices of sample 3 and sample 2 have been observed to be relatively low. From the toughness index values, it has been observed that sample 1 may be friable at plastic limit while the sample 2 has highest shear strength at plastic limit followed by sample 3 and sample 4. The flow curves for the four samples are shown in Fig 2. 
Zaid Yaqoob Mir Rangrez.et.al. Int. Journal of Engineering Research and Application www.ijera.com ISSN : 2248-9622, Vol. 7, Issue 1, ( Part -2) January 2017, pp.11-21

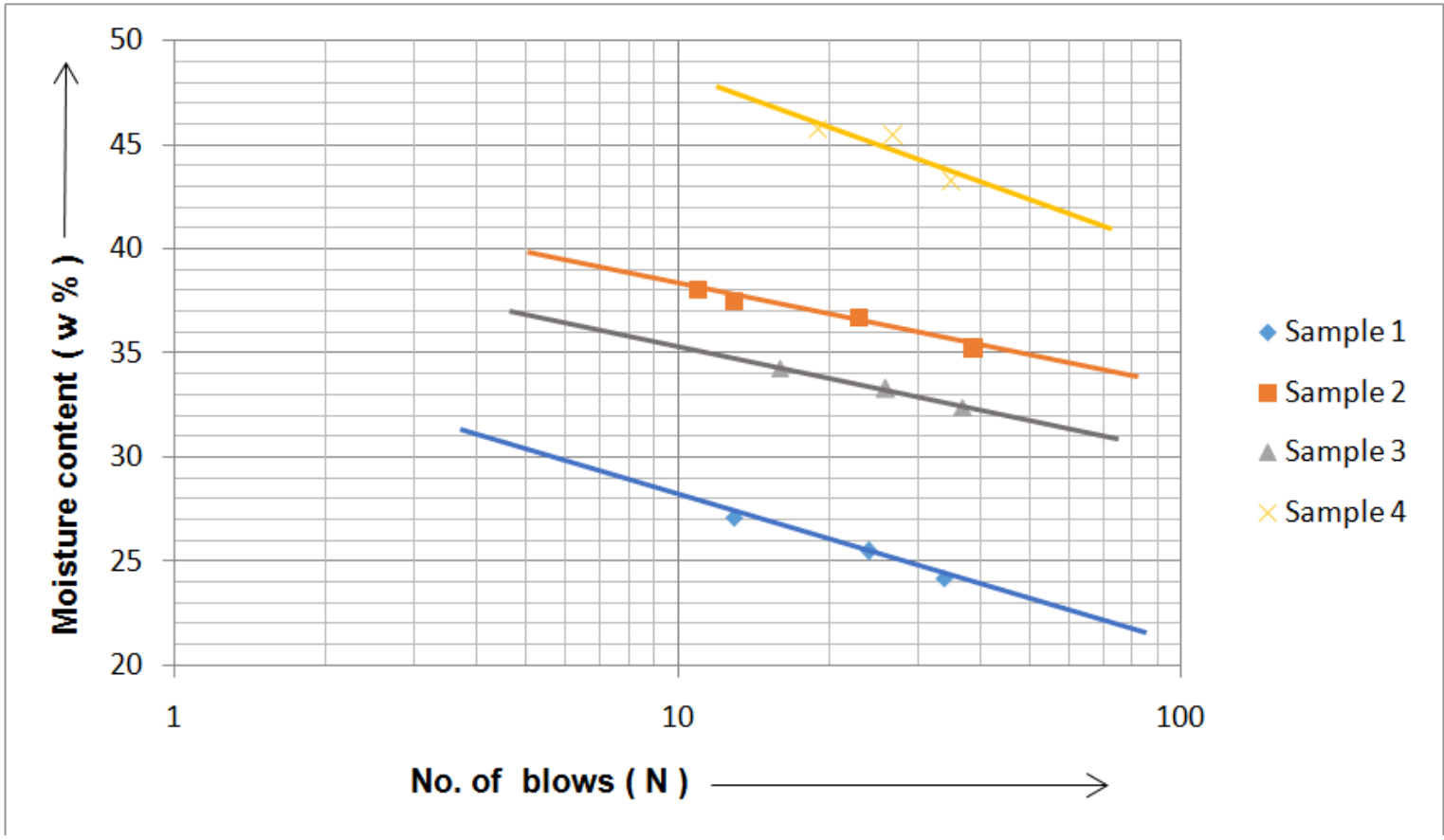

\subsection{Classification}

From the values of liquid limit and plasticity index, the sample 1 plots within the CL-ML region of the plasticity chart. Sample 2 and Sample 4 plots within the $\mathrm{CI}$ region and sample 3 within the $\mathrm{CL}$ region.

Fig 2 Flow curves.

\subsection{Compaction characteristics}

The compaction curves for the samples are shown in Fig 3. The test results are given in Table 3 . The initial concave portion in the curves is due to the presence of sand which results in bulking phenomenon.

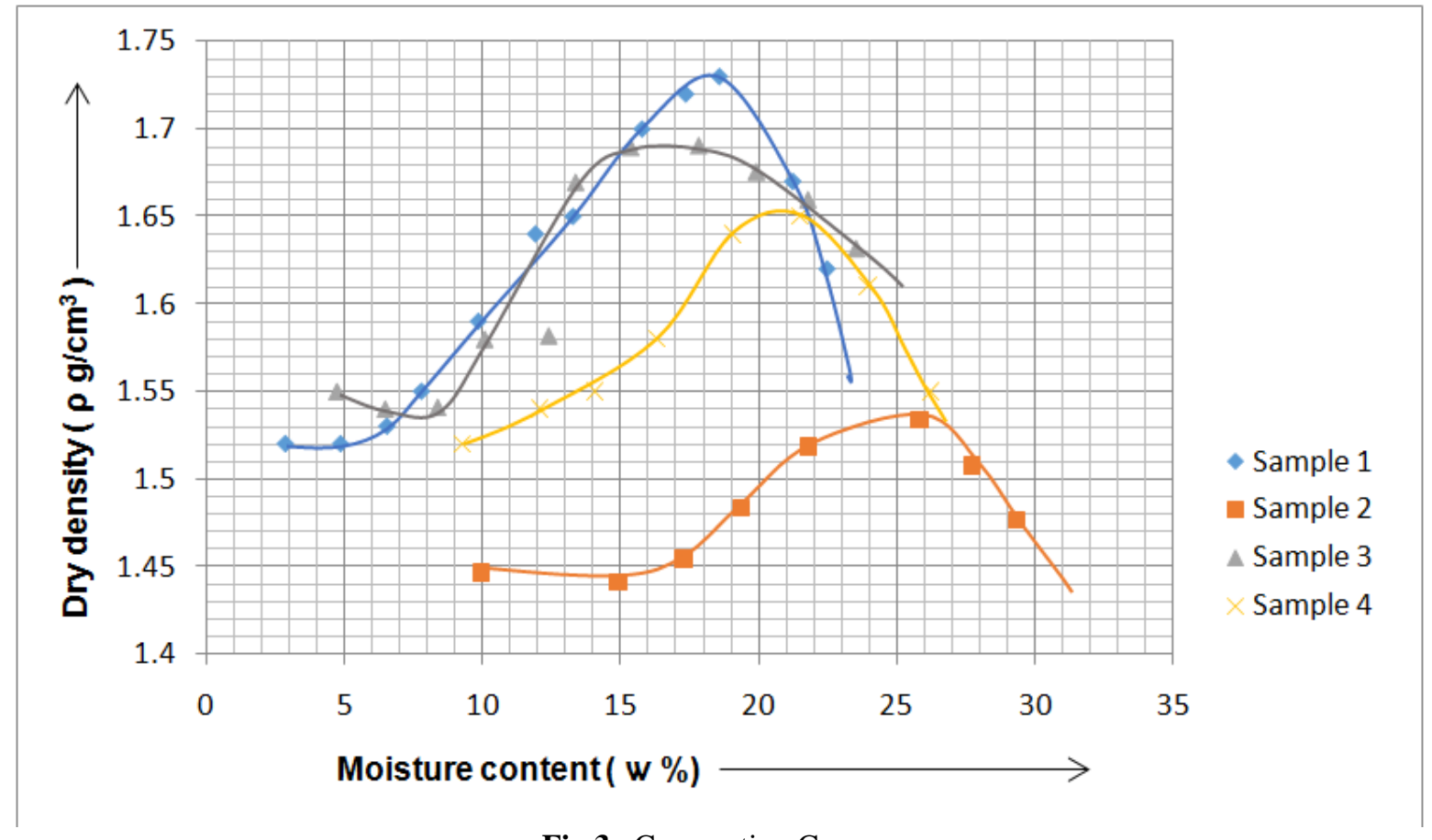

\subsection{Shear strength:}

Fig 3 Compaction Curves. 
Zaid Yaqoob Mir Rangrez.et.al. Int. Journal of Engineering Research and Application

www.ijera.com ISSN : 2248-9622, Vol. 7, Issue 1, ( Part -2) January 2017, pp.11-21

The values of various shear strength parameters; viz, angle of shear resistance $(\varphi)$ and cohesion intercept

(c) are given in the Table 3. Fig 4 shows the failure envelopes.

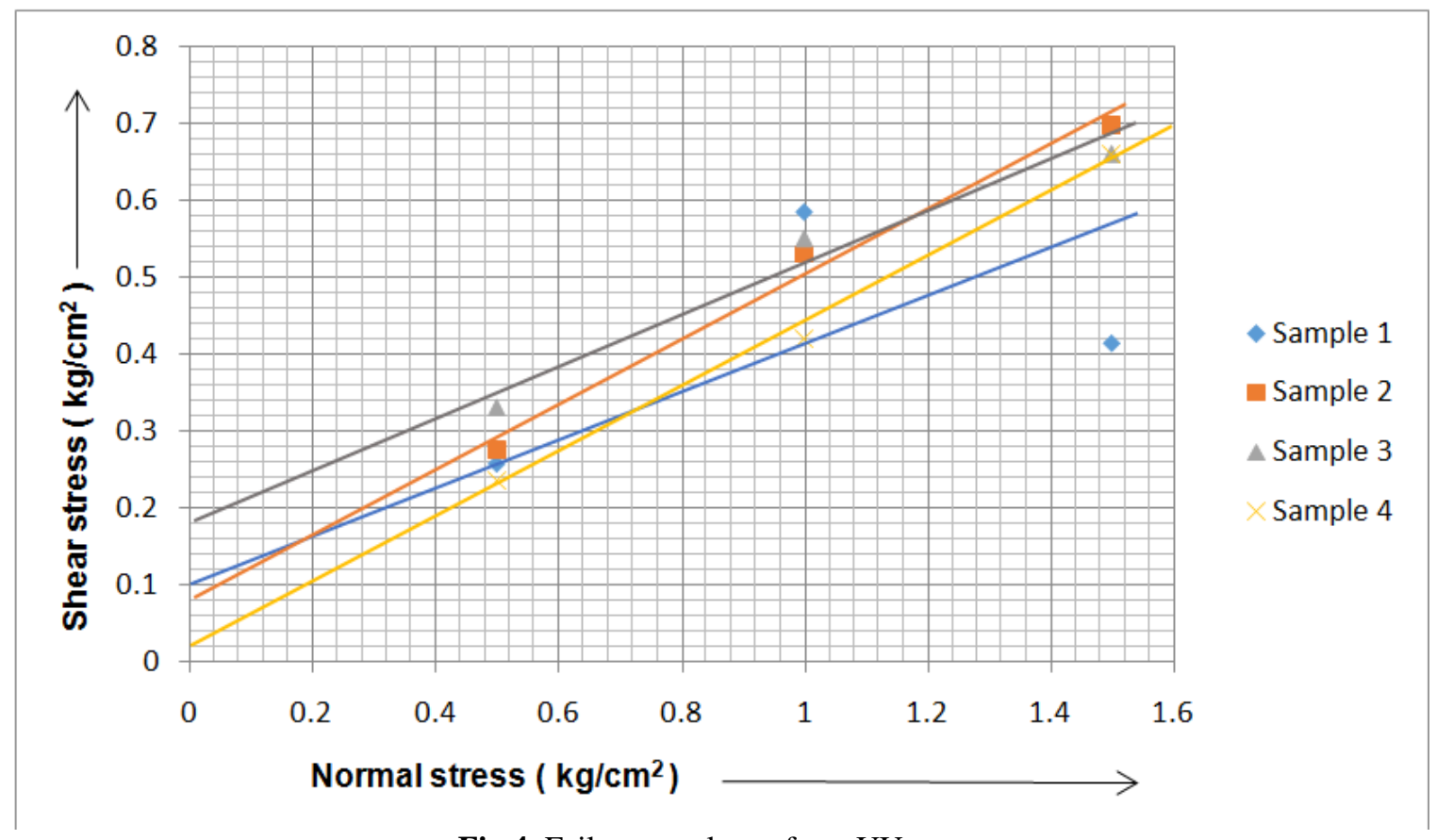

Fig 4 Failure envelopes from UU tests.

\subsection{CBR value:}

The CBR value of the material when compacted, in general, is low. This may restrict its application in the construction of sub base and base course. The CBR values of the samples are given in Table 3 . The loadpenetration curves for the samples are shown in Fig 5.

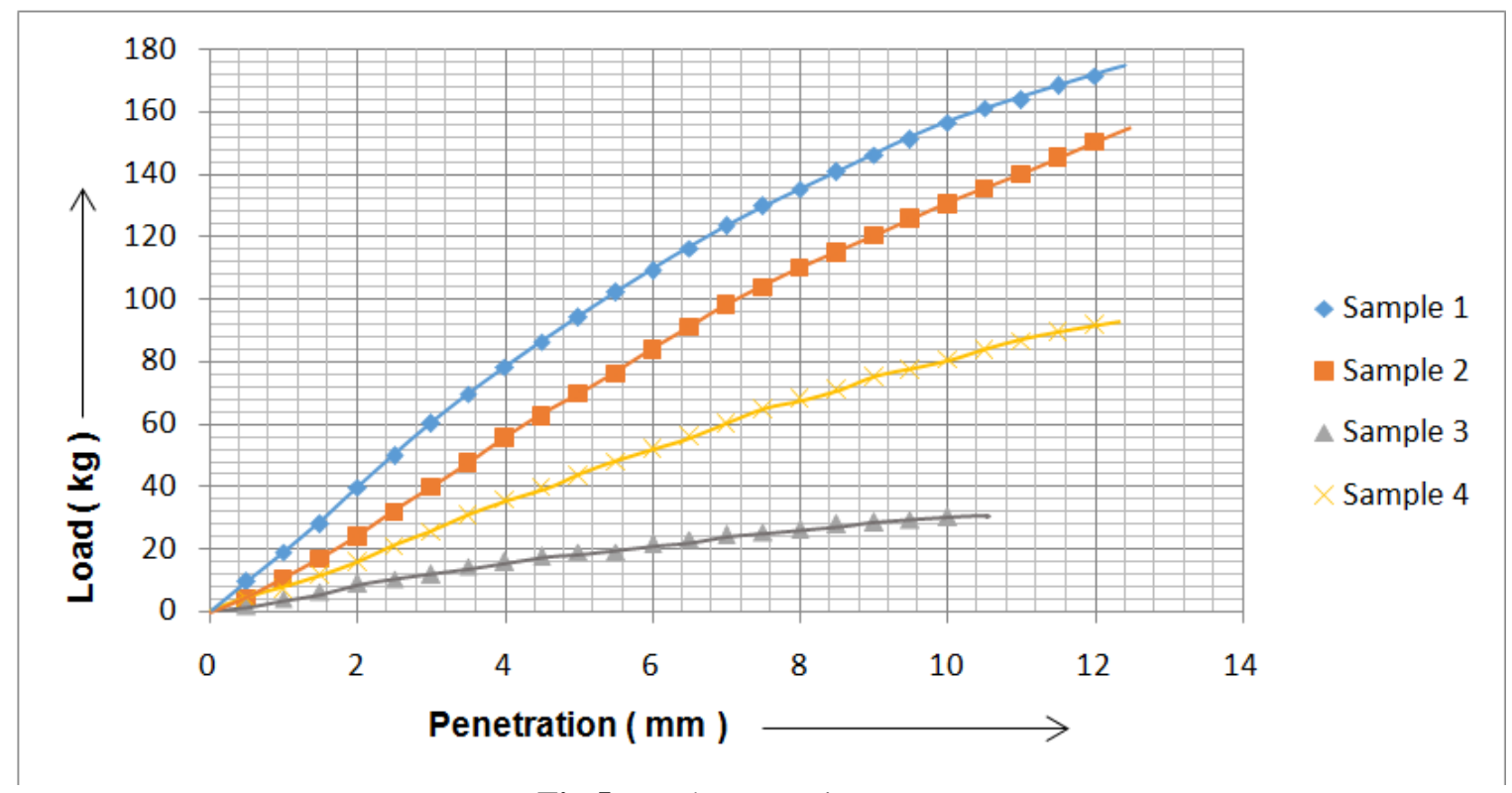

4.8 Compressibility characteristics:

Fig 5 Load-Penetration curves.

The values of various compressibility parameters are given in Table 3. From the observations, the material 
Zaid Yaqoob Mir Rangrez.et.al. Int. Journal of Engineering Research and Application

www.ijera.com ISSN : 2248-9622, Vol. 7, Issue 1, ( Part -2) January 2017, pp.11-21

was found to have very low to intermediate compressibility when compacted. The swelling indices of the material during unloading were also found to be low. Fig 6 and Fig 7 shows the e- $\sigma$ and e$\log \sigma$ plots respectively.

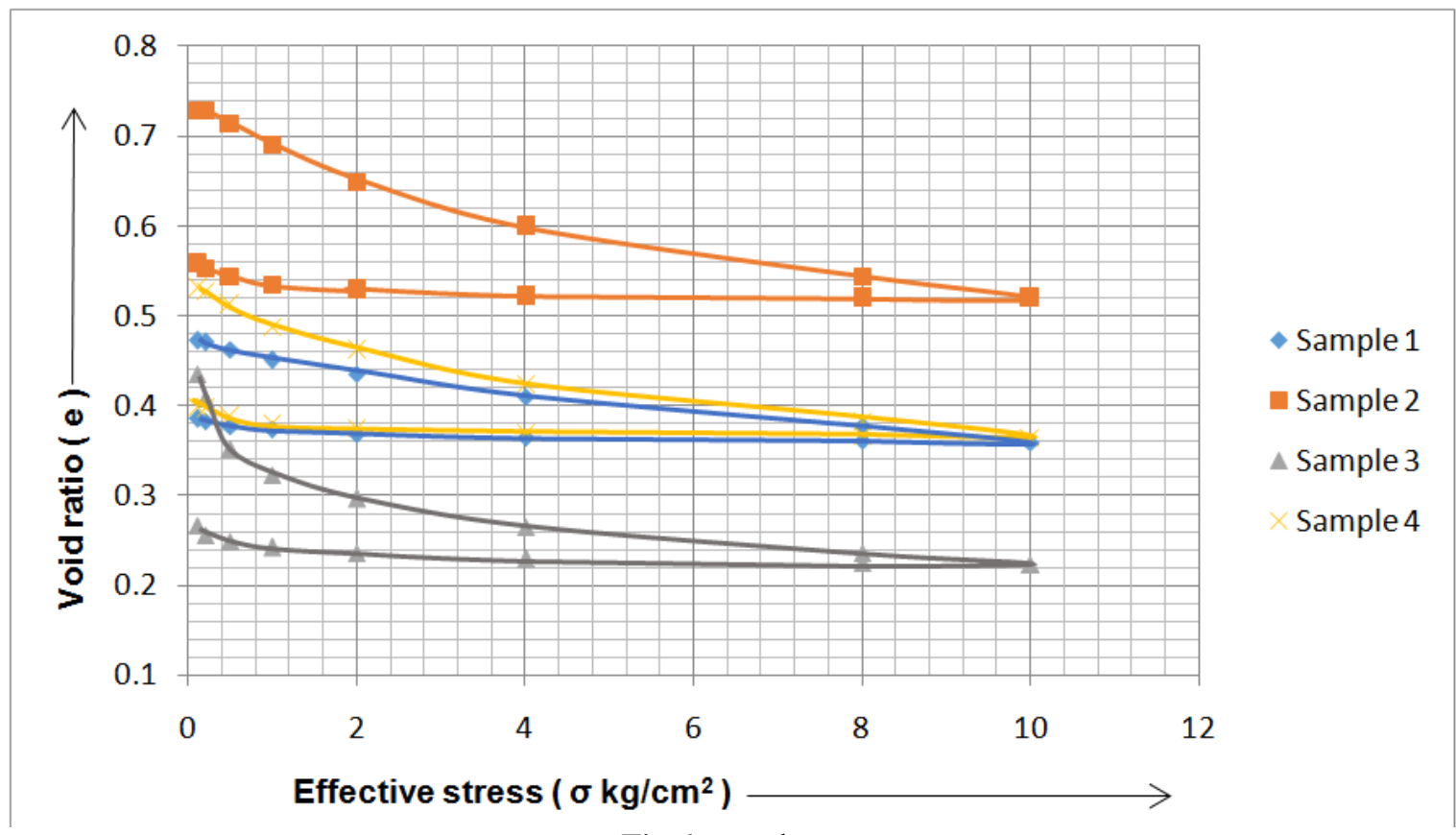

Fig 6 e- $\sigma$ plots.

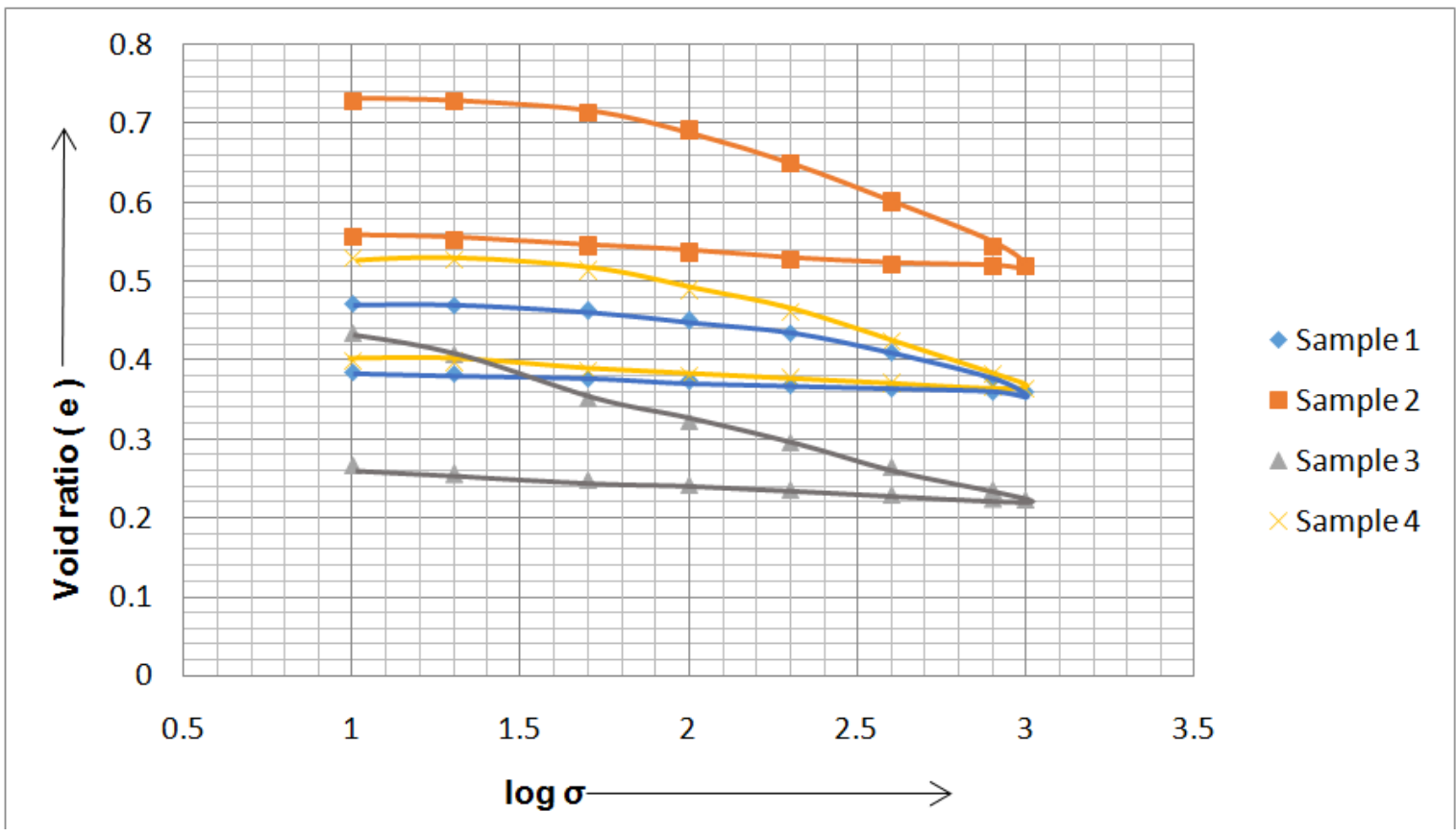

Fig 7 e- $\log \sigma$ plots.

4.9 Permeability characteristics: 
The values of coefficient of permeability for different samples are given in Table 3 . The material was found to be less permeable when compacted.

\subsection{Unconfined compressive strength:}

The values of unconfined compressive strength of the samples are given in the Table 3 . Fig 8 shows the stress-strain behaviour of the various samples.

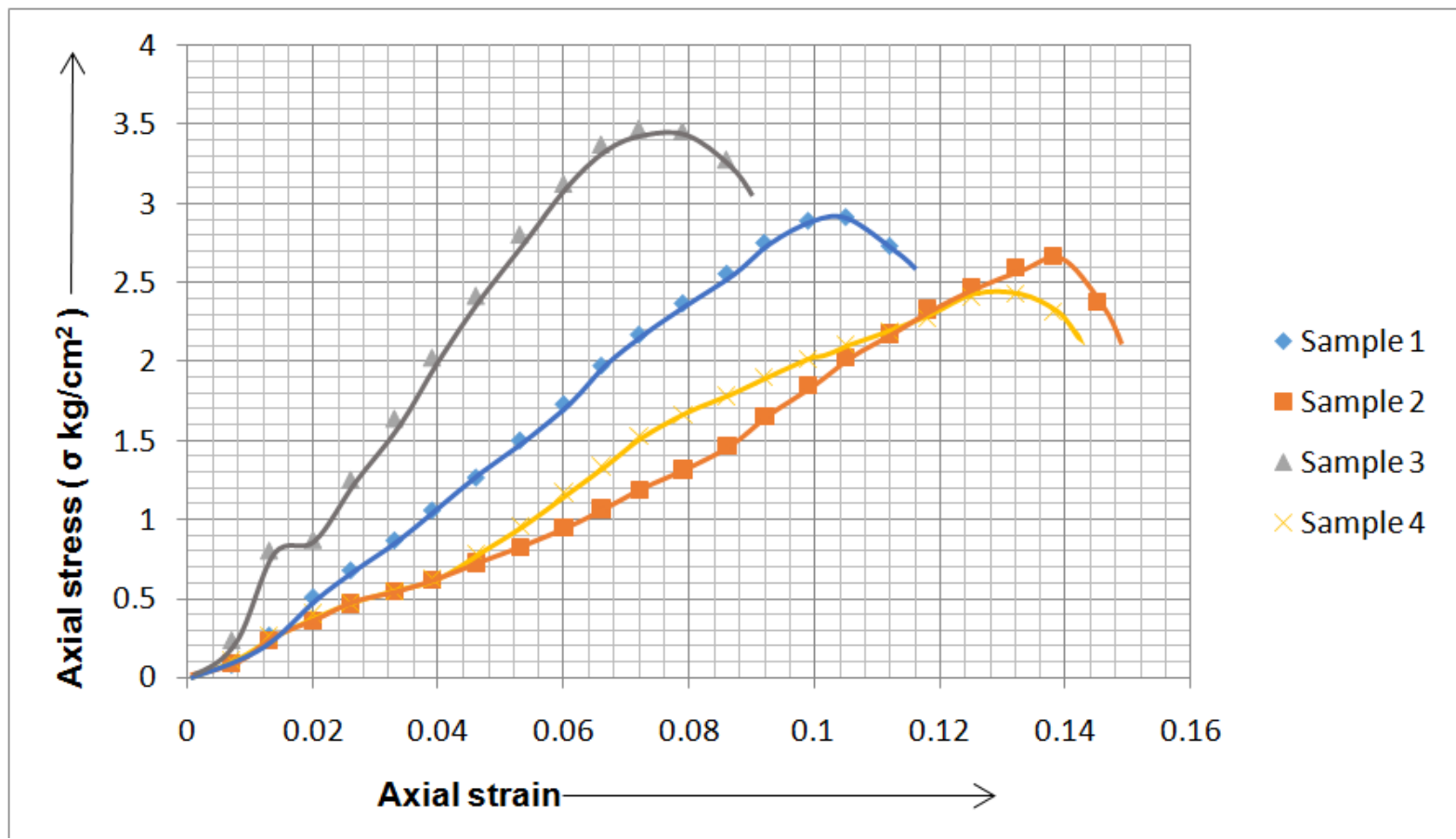

Fig 8 Stress-strain curves from UCS tests.

It has been observed that the material available at the chosen locations is having a good unconfined compressive strength. The stress-strain curves indicate decrease in stress after the materials are strained beyond the peak stress thus showing the work-softening behaviour.
From the above discussion, the suitability of the characterized dredged material from various location of flood spill channel bed for various potential constructional uses can be summarized as given in Table 4 :

Table 4. Suitability of characterized dredged material

\begin{tabular}{|c|c|c|c|c|}
\hline Sample No. & Sample 1 & Sample 2 & Sample 3 & Sample 4 \\
\hline Soil group & CL-ML & $\mathrm{CI}$ & $\mathrm{CL}$ & CI \\
\hline Value as Subgrade & Poor to fair & Poor to fair & Poor to fair & Poor to fair \\
\hline $\begin{array}{r}\text { Value as } \\
\text { Sub-base } \\
\end{array}$ & Not suitable & Not suitable & Not suitable & Not suitable \\
\hline Value as Base course & Not suitable & Not suitable & Not suitable & Not suitable \\
\hline $\begin{array}{c}\text { Value of embankment } \\
\text { when compacted }\end{array}$ & $\begin{array}{c}\text { Stable; } \\
\text { Impervious cores } \\
\text { and blankets. }\end{array}$ & $\begin{array}{c}\text { Stable; } \\
\text { Impervious } \\
\text { cores and } \\
\text { blankets. }\end{array}$ & $\begin{array}{c}\text { Stable; } \\
\text { Impervious } \\
\text { cores and } \\
\text { blankets. }\end{array}$ & $\begin{array}{c}\text { Stable; } \\
\text { Impervious } \\
\text { cores and } \\
\text { blankets. }\end{array}$ \\
\hline $\begin{array}{c}\text { Value of foundation when } \\
\text { compacted }\end{array}$ & $\begin{array}{l}\text { Fair to good } \\
\text { bearing }\end{array}$ & $\begin{array}{l}\text { Fair to good } \\
\text { bearing }\end{array}$ & $\begin{array}{l}\text { Fair to good } \\
\text { bearing }\end{array}$ & $\begin{array}{l}\text { Fair to good } \\
\text { bearing }\end{array}$ \\
\hline $\begin{array}{l}\text { Value as compacted earth } \\
\text { lining for canal sections }\end{array}$ & Good & Good & Good & Good \\
\hline
\end{tabular}


Table 4. Suitability of characterized dredged material ( Continued )

\begin{tabular}{|c|c|c|c|c|}
\hline Sample No. & Sample 1 & Sample 2 & Sample 3 & Sample 4 \\
\hline $\begin{array}{c}\text { Workability as a raw } \\
\text { material* }\end{array}$ & Fair to good & Fair to good & Fair to good & Fair to good \\
\hline $\begin{array}{c}\text { Value as compacted clay } \\
\text { liners. }\end{array}$ & Good & Good & Good & Good \\
\hline $\begin{array}{c}\text { Value as a compacted } \\
\text { landfill. }\end{array}$ & Fair to good & Fair to good & Fair to good & Fair to good \\
\hline
\end{tabular}

"As a raw material for the manufacture of bricks and tiles. (additional tests required and additives may be needed for such an explicit application)

\section{CONCLUSIONS}

From the results obtained, following conclusions can be made:

1. The dredged material available at the bed of flood spill channel, in general, is fine grained soil. The material being clayey silt with small amount of fine sand.

2. The CBR value of the material, in general, is low. Thus its use as a construction material for sub-base or base-course is relatively restricted. However, it can be put to use as a subgrade material for rural roads.

3. The material being less permeable when compacted, it can be used as an embankment material in impervious cores and blankets. Moreover, this property also permits its use as compacted earth lining for canal sections and as compacted clay liners.

4. The shear strength of the material is relatively fair to good and therefore, it can be used as a foundation soil in areas having soil unsuitable for construction purpose. Moreover, the material can also be used as compacted land fill.

5. The material being comprised of silt and clay, it may also find its use as a raw material for the manufacture of bricks and tiles, though, more specific chemical and additional tests may be required. Also the introduction of additives may be required for such an explicit application.

6. Although beyond the engineering domain, the soil of flood spill channel being of flood transported origin, the same can well be utilized by floriculture, landscaping and agriculture department for its good general line fertility.

Thus, by taking above conclusions into consideration, one can plan an effective utilization of the dredged material which will be obtained from the bed of Jhelum flood spill channel.

\section{FUTURE SCOPE OF WORK}

The following work can be done in order to explore more about the suitability of dredged material from Jhelum flood spill channel:

1. Conducting the triaxial tests on the material.

2. Determining the various geotechnical parameters for the case of heavy compaction.

3. Organic content of the material may also be assessed.

4. The dredged material seems to be a potential candidate for stabilization and thus, after carrying out the stabilization of the dredged material using various available stabilizers like quick lime, cement, etc, its suitability for various engineering uses can be explored.

\section{ACKNOWLEDGEMENT}

The authors would like to acknowledge the whole staff of Road Research and Material Testing Laboratory, Srinagar, Kashmir for their constant help and support during the execution of this research work.

\section{REFERENCES}

[1] "Urban Nightmare" , Drainage is the key, Retrieved from http://www.indiaenvironmentportal.org.in/med ia/iep/infographics/Urban\%20Nightmare/index .htm

[2] Evangelin Ramani Sujatha, Kumara Raja G, Poojitha D, Navroj Ravi and Kumar Abishek (2014), Evaluation of Geotechnical parameters of Sand Silt Clay mixtures obtained from Kollidam Riverbed in Tiruchipalli Tamil Nadu, Electronic Journal of Geotechnical Engineering, vol.19, Bundle $\mathrm{Z}_{3}$, pp. 1736117368.

[3] Hua Yu and William J. Likos( 2014), Beneficial use of Dredged materials in Great Lakes commercial ports for transportation projects, Technical Report, CFIRE 07-06. 
[4] Manas R. Das, Durga P Subudhi, S. Signum, Amit Das, A.T. Ashutosh, D. Yadav (2014), Geotechnical characterization of Dredged Mud from Chilka Lake, International Journal of Advanced Research in Civil, Structural, Environmental and Infrastructure Engineering and Developing, vol. 2, pp. 36-41.

[5] Walid Maherzi and Farouk Ben Abdelghani (2014), Dredged Marine Raw Sediments Geotechnical Characterization for their Reuse in Road Construction, Engineering Journal, vol. 18(4), pp. 27-37.

[6] C. Sheehan, J. Harrington, J.P. Murphy, and J. Riordan (2008), An investigation into potential beneficial uses of dredged material in Ireland, WEDA XXVII and Texas TAMU 39th Dredging Seminar, pp. 425-444, St. louis, U.S.A. 